\title{
Alien spiders: First record of Loxosceles gaucho Gertsch, 1967 (Araneae: Sicariidae) in the Amazon region, Brazil
}

\author{
Marlus Queiroz Almeida ${ }^{1,3}$; João Rafael Alves-Oliveira ${ }^{1,4}$; Diego Matheus de Mello Mendes ${ }^{2,5}$; Rafael Sobral ${ }^{1,6}$; \\ Alberto Moreira da Silva-Neto ${ }^{2,7}$ \& José Wellington de Morais ${ }^{1,8}$
}

\footnotetext{
${ }^{1}$ Instituto Nacional de Pesquisas da Amazônia (INPA), Coordenação de Biodiversidade (CBIO), Laboratório de Sistemática e Ecologia de Invertebrados do Solo (LSEIS). Manaus, AM, Brasil.

2 Instituto Nacional de Pesquisas da Amazônia (INPA), Coordenação de Biodiversidade (CBIO), Laboratório de Entomologia Sistemática, Urbana e Forense (LESUF). Manaus, AM, Brasil.

3 ORCID: http://orcid.org/0000-0001-5580-088X. E-mail: marlusqaz00@gmail.com (corresponding author)

${ }^{4}$ ORCID: http://orcid.org/0000-0002-2300-8780.E-mail: jraoliveira.bio@gmail.com

${ }^{5}$ ORCID: http://orcid.org/0000-0001-5037-9686. E-mail: diego.mello.mendes@gmail.com

${ }^{6}$ ORCID: http://orcid.org/0000-0002-4975-1193.E-mail: rafaelsobralves@gmail.com

7 ORCID: http://orcid.org/0000-0002-4522-3756. E-mail: bio.alberto@gmail.com

${ }^{8}$ ORCID: http://orcid.org/0000-0003-3801-7054. E-mail: moraisjw@gmail.com
}

\begin{abstract}
We present the first record for Loxosceles gaucho Gertsch, 1967 in the Amazonian region of Brazil. Four males, fifteen females and forty-nine immatures were collected in different places in Manaus, Amazonas, Brazil. This is the third species of Loxosceles reported in the Amazon region along with L. amazonica Gertsch, 1967, and L. similis Moenkhaus, 1898. This is the first record of an invasive species of a venomous animal in the state of Amazonas, Brazil, which is noteworthy due to its synanthropic habit, which increases the risk to the local population.
\end{abstract}

Key-Words. Manaus; Aranha marrom; Brown recluse spider; Venomous species.

\section{INTRODUCTION}

Loxosceles Heinecken \& Lowe, 1832 is a cosmopolite genus of spiders that are commonly known as "violin spiders", "recluse spiders" or "brown recluse spiders" in North America (ValdezMondragón et al., 2018). In Brazil, Loxosceles spiders are better known as "aranhas-marrons" (brown spiders, in Portuguese) and are distributed through the whole country (Table 1).

Many species in the genus can cause severe envenoming of humans, which is known as loxoscelism (Swanson \& Vetter, 2006). The venom of Loxosceles causes an intense inflammatory process around the site of the bite along with vasoconstriction, edema, hemorrhage and focal necrosis, therefore the clinical picture may be cutaneous or cutaneous-visceral (Barbaro \& Cardoso, 2003). In Brazil, Loxosceles intermedia Mello-Leitão, 1934, Loxosceles laeta (Nicolet, 1849) and Loxosceles gaucho Gertsch, 1967 are the main species responsible for in-house bites on humans (Cardoso et al., 2003). There is a single species recorded In Amazonas, Brazil, Loxosceles amazonica Gertsch, 1967 (Gertsch, 1967; Almeida et al., 2017).

Loxosceles gaucho is an endemic species from south and southwest of Brazil, being its type locality known for São Paulo (Gertsch, 1967). The female of this species is easily identifiable by the presence of a transverse and sclerotized plate firmly holding the seminal receptacles in genitalia of female (Figs. 2B-C), while males are easily identified by having the palpal femur 4 times longer than wide and by the embolus thick at base, forming sinuous curve (Figs. 1B-C) (Gertsch, 1967). The distribution of the species is currently known only for the states of São Paulo, Minas Gerais, Rio Grande do Sul and Paraná (Gertsch, 1967; Fischer, 1994). The purpose of this work is to record for the first time $L$. gaucho in northern Brazil (Amazonas, Manaus), to report a checklist of the known Brazilian species of Loxosceles and to present an identification key to the known Loxosceles species of Amazonas, Brazil. 
Table 1. Species of Loxosceles recorded for Brazil. Data based exclusively on taxonomic papers included in the World Spider Catalog, version 20.5. 2019.

\begin{tabular}{|c|c|}
\hline Species & Distribution \\
\hline Loxosceles adelaida Gertsch, 1967 & ${ }^{1}$ Rio de Janeiro and 'São Paulo \\
\hline Loxosceles amazonica Gertsch, 1967 & $\begin{array}{l}1,3 \text { Amazonas, }{ }^{2} \text { Pará, }{ }^{2} \text { Tocantins, }{ }^{2} \text { Bahia, }{ }^{2} \text { Ceará, }{ }^{2} \text { Maranhão, }{ }^{2} \text { Paraiba, }{ }^{2} \text { Pernambuco, }{ }^{2} \text { Piaui, }{ }^{4} \text { Rio Grande do Norte } \\
\text { and }{ }^{2} \text { Mato Grosso }\end{array}$ \\
\hline Loxosceles anomala (Mello-Leitão, 1917) & ${ }^{8}$ Minas Gerais \\
\hline Loxosceles cardosoi Bertani, von Schimonsky \& Gallão, 2018 & ${ }^{5}$ Bahia \\
\hline Loxosceles carinhanha Bertani, von Schimonsky \& Gallão, 2018 & ${ }^{5}$ Bahia \\
\hline Loxosceles chapadensis Bertani, Fukushima \& Nagahama, 2010 & ${ }^{5}$ Bahia \\
\hline Loxosceles ericsoni Bertani, von Schimonsky \& Gallão, 2018 & ${ }^{5}$ Minas Gerais \\
\hline Loxosceles gaucho Gertsch, 1967 & ${ }^{1}$ São Paulo, ${ }^{1,9}$ Paraná, ${ }^{1}$ Rio Grande do Sul and Amazonas* \\
\hline Loxosceles hirsuta Mello-Leitão, 1931 & ${ }^{6}$ Paraná and ${ }^{6}$ Rio Grande do Sul \\
\hline Loxosceles immodesta (Mello-Leitão, 1917), & ${ }^{8}$ São Paulo \\
\hline Loxosceles intermedia Mello-Leitão, 1934 & ${ }^{7}$ São Paulo, ${ }^{1,7}$ Rio de Janeiro, ${ }^{9}$ Paraná and Distrito Federal \\
\hline Loxosceles karstica Bertani, von Schimonsky \& Gallão, 2018 & ${ }^{5}$ Bahia and ${ }^{5}$ Minas Gerais \\
\hline Loxosceles laeta (Nicolet, 1849) & ${ }^{1}$ Rio Grande do Sul, ${ }^{1}$ Santa Catarina, ${ }^{9}$ Paraná, ${ }^{1}$ São Paulo, ${ }^{1}$ Minas Gerais and ${ }^{10}$ Rio de Janeiro \\
\hline Loxosceles muriciensis Fukushima, de Andrade \& Bertani, 2017 & ${ }^{4}$ Alagoas \\
\hline Loxosceles niedeguidonae Gonçalves-de-Andrade, Bertani, Nagahama \& Barbosa, 2012 & 11Piaui \\
\hline Loxosceles puortoi Martins, Knysak \& Bertani, 2002 & ${ }^{12}$ Tocantins \\
\hline Loxosceles similis (Moenkhaus 1898), & ${ }^{1}$ Pará, 'São Paulo and ${ }^{1}$ Minas Gerais \\
\hline Loxosceles troglobia Souza \& Ferreira, 2018 & ${ }^{13}$ Bahia \\
\hline Loxosceles willianilsoni Fukushima, de Andrade \& Bertani, 2017 & ${ }^{4}$ Rio Grande do Norte \\
\hline
\end{tabular}

${ }^{1}$ Gertsch, 1967; ${ }^{2}$ Silveira, 2015; ${ }^{3}$ Almeida et al., 2017; ${ }^{4}$ Fukushima et al., 2017; ${ }^{5}$ Bertani et al., 2018b; ${ }^{6}$ Mello-Leitão, 1931; ${ }^{7}$ Mello-Leitão, 1934; ${ }^{8}$ Mello-Leitão, $1917 ;{ }^{9}$ Marques-da-Silva \& Fischer, 2005; ${ }^{10}$ Silveira, 2009; "'Gonçalves-de-Andrade et al., 2012; ${ }^{12}$ Martins et al., 2002; ${ }^{13}$ Souza \& Ferreira, 2018.

\section{MATERIAL AND METHODS}

The specimens were captured in the period from 2016 to 2018 in two popular farmers market, one located at the central region of the Manaus city, at Manaus Moderna farmers market $\left(03^{\circ} 08^{\prime} 28.20^{\prime \prime} \mathrm{S}, 60^{\circ} 01^{\prime} 19.35^{\prime \prime} \mathrm{W}\right)$ and the other at the eastern part of the city, at the Coroado farmers market $\left(03^{\circ} 05^{\prime} 00.37^{\prime \prime} \mathrm{S}, 59^{\circ} 58^{\prime} 49.18^{\prime \prime} \mathrm{W}\right)$. The spiders were located in cardboard boxes and in debris next to the farmers market and were manually collected. Egg sacs and immatures were also collected at the Coroado farmers market.

Specimens were deposited in the Invertebrate Zoology Collection at Instituto Nacional de Pesquisas da Amazônia (INPA). Specimen identification was made using Gertsch (1967). The left male palp was illustrated in prolateral view and female spermathecae were illustrated in prolateral and retrolateral view. Digital images were taken using a stereomicroscope Leica M205A equipped with a camera (Leica DMC4500), the illustrations were made in an Adobe Photoshop CC 2017 and the distribution map was created using SimpleMappr (Shorthouse, 2010).

Material examined (4 $\sigma^{x}$ and 15 \%): $2 \sigma^{x}$ and 2 , BRAZIL, Amazonas, Manaus, Centro, $\left(03^{\circ} 08^{\prime} 28.20^{\prime \prime}\right.$, $\left.60^{\circ} 01^{\prime} 19.35^{\prime \prime} \mathrm{W}\right)$ 26.viii.2016, M.Q. Almeida leg.; 2 o" and 3 \%, 49 juveniles, BRAZIL, Amazonas, Manaus, Coroado, $\left(03^{\circ} 05^{\prime} 00.37^{\prime \prime S}, 59^{\circ} 58^{\prime} 49.18^{\prime \prime W}\right), 09 . v i .2018$, M.Q. Almeida leg.; 9 \% and 52 specimens prelarva state, BRAZIL, Amazonas, Manaus, Coroado, (38'28.20"S, 60¹'19.35"W), 09.vi.2018, M.Q. Almeida leg.; 1 o BRAZIL, Amazonas, Manaus, Coroado, (0308'28.20"S, $\left.60^{\circ} 01^{\prime 1} 19.35^{\prime \prime W}\right), 09 . v i .2018$, M.Q. Almeida leg. The specimens will be deposited in the Invertebrate Collection of the Instituto Nacional de Pesquisas da Amazônia (INPA), Manaus, Amazonas, Brazil.

\section{RESULTS}

A total of 68 specimens of L. gaucho were collected, four males (Fig. 1), fifteen females (Figs. 2, 3A) and forty-nine juveniles. Egg sacs were found with 52 specimens in prelarva state (Figs. 3B-E). This is the second record of a Loxosceles species to state of Amazonas, Brazil, as previously, only $L$. amazonica was registered. These two species can be distinguishable by the identification key below.

\section{Key to the Loxosceles species in Amazonas state, Brazil (Modified from Gertsch, 1967)}

\section{Males}

1. Palpal tarsus as wide as palpal tibia. Apex of embolus forming a sinuous curve (Figs. 1B-C) ..Loxosceles gaucho Gertsch

- Palpal tarsus thinner than palpal tibia. Apex of embolus with a mild curvature (Figs. 4B-C). Loxosceles amazonica Gertsch

\section{Females}

1. Spermathecae with a transverse and sclerotized plate and absence of globular lobes at apex (Fig. 2C) ..................... Loxosceles gaucho Gertsch

- Spermathecae lacking a sclerotized plate and presence of a group of small globular lobes at apex (Fig. 4D) .... Loxosceles amazonica Gertsch

Of the five Brazilian regions, the North and the Central-West have the lesser number of species of Loxosceles recorded (3 species in each of these regions) 


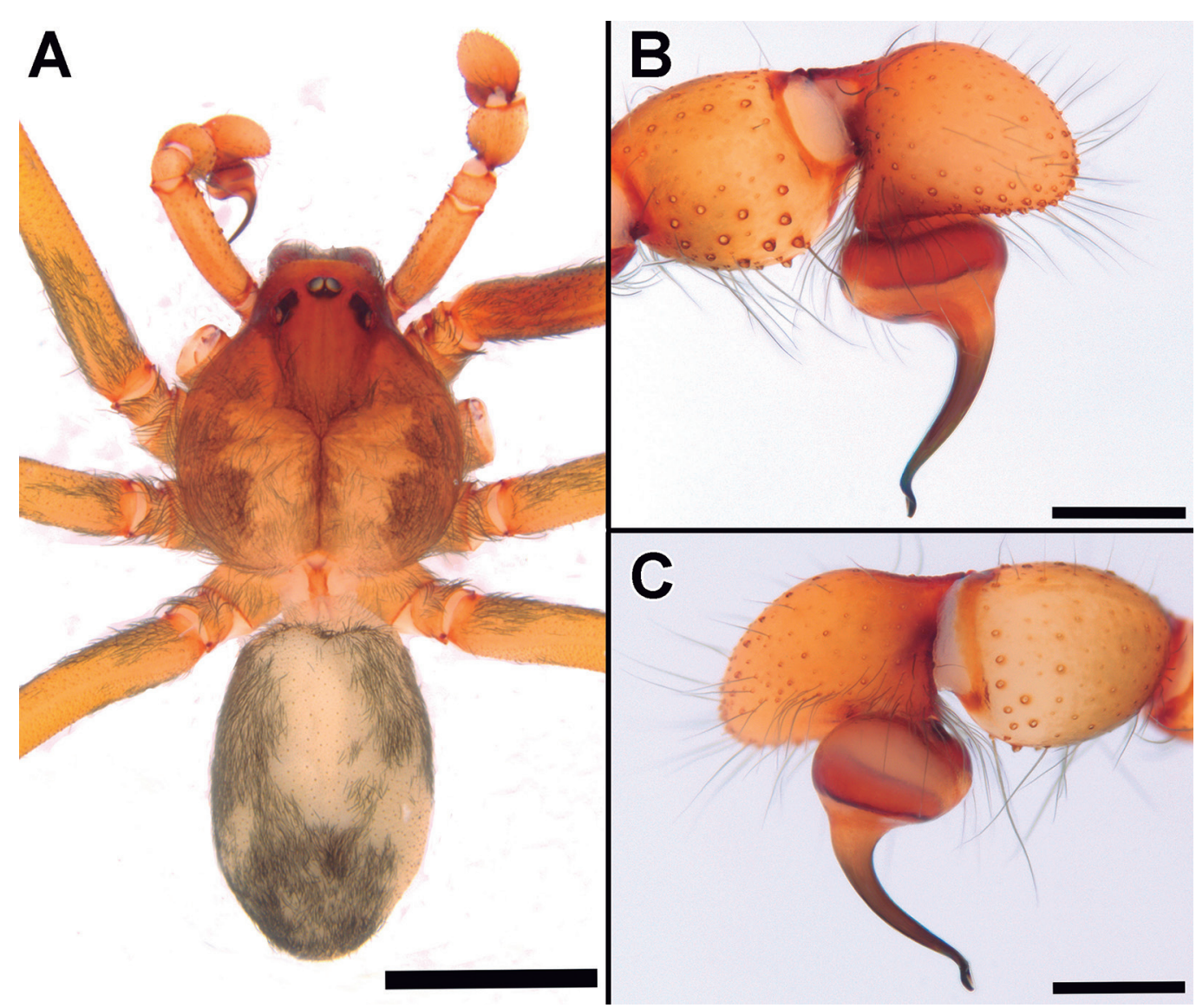

Figure 1. Loxosceles gaucho (male). (A) habitus; (B) palp, retrolateral view; (C) palp, prolateral view. Scale bars: A, 3 mm; B-C, 2 mm.

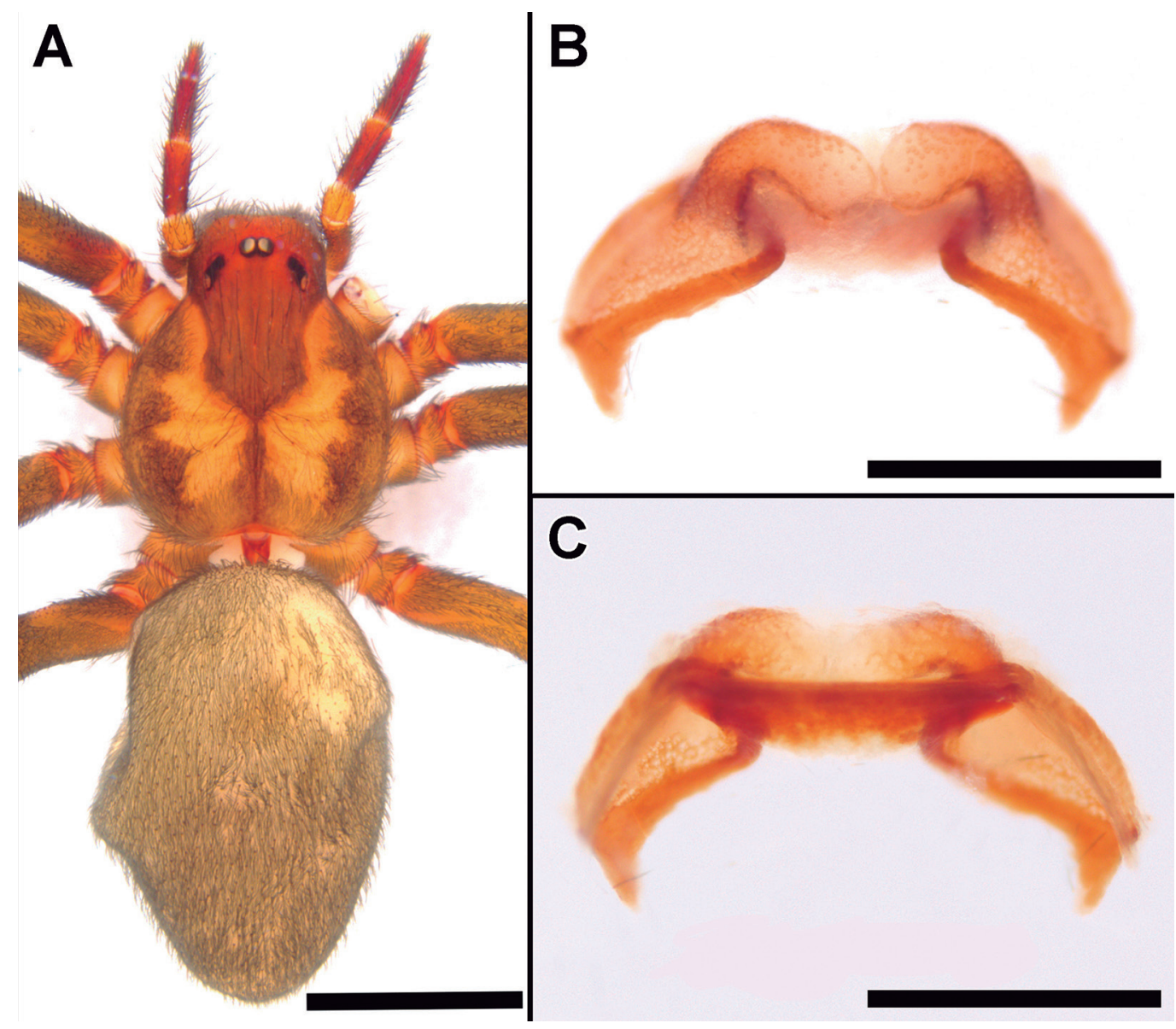

Figure 2. Loxocesles gaucho (female). (A) habitus; (B) spermathecae, ventral view; (C) epigynum, dorsal view. Scale bars: A, 3 mm; B-C, 2 mm. 

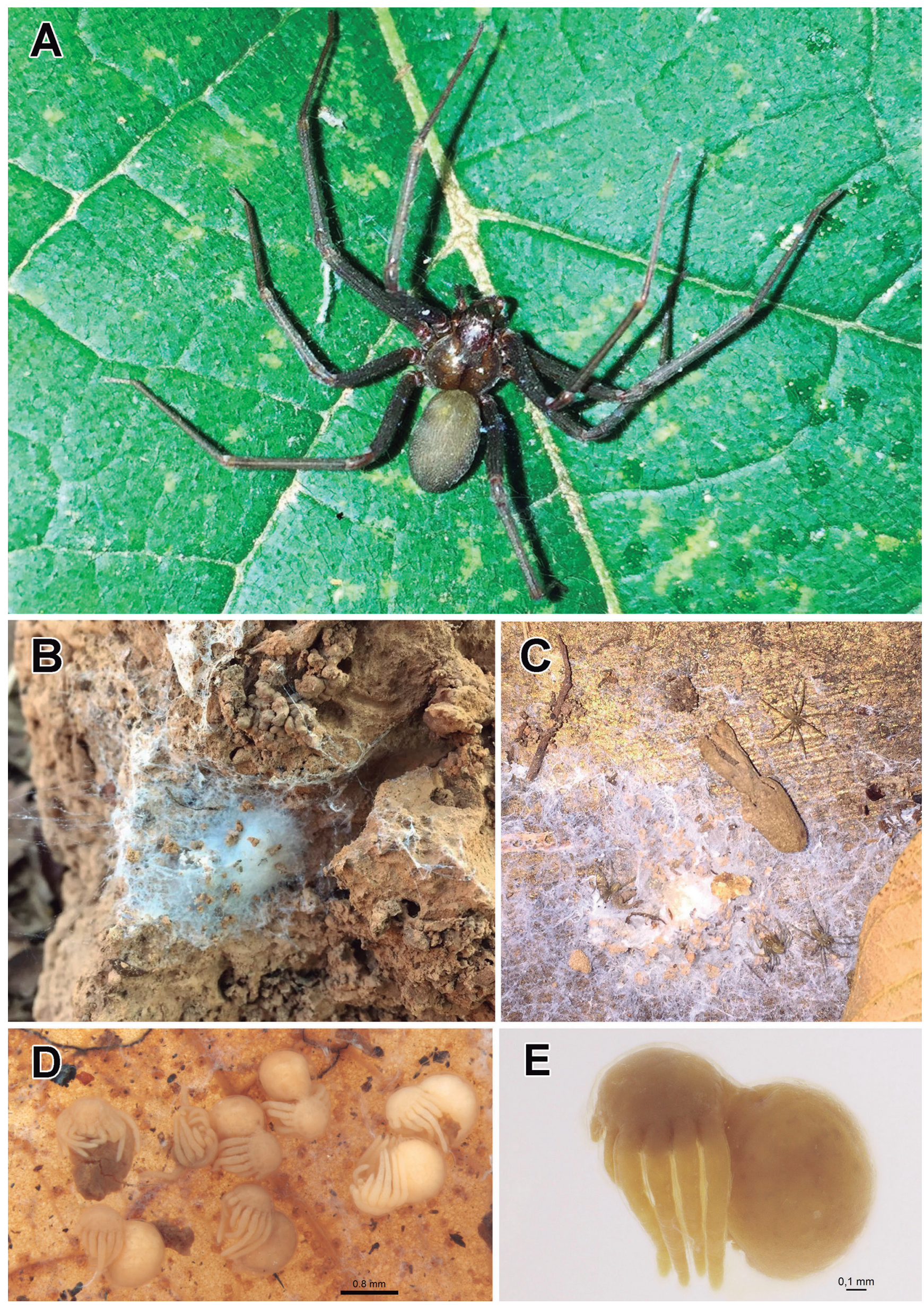

Figure 3. Loxocesles gaucho. (A) (female), live specimen; (B) eggsacs; (C) immatures live specimens; (D) specimens in prelarva state; (E) specimen in prelarva state, detail. 

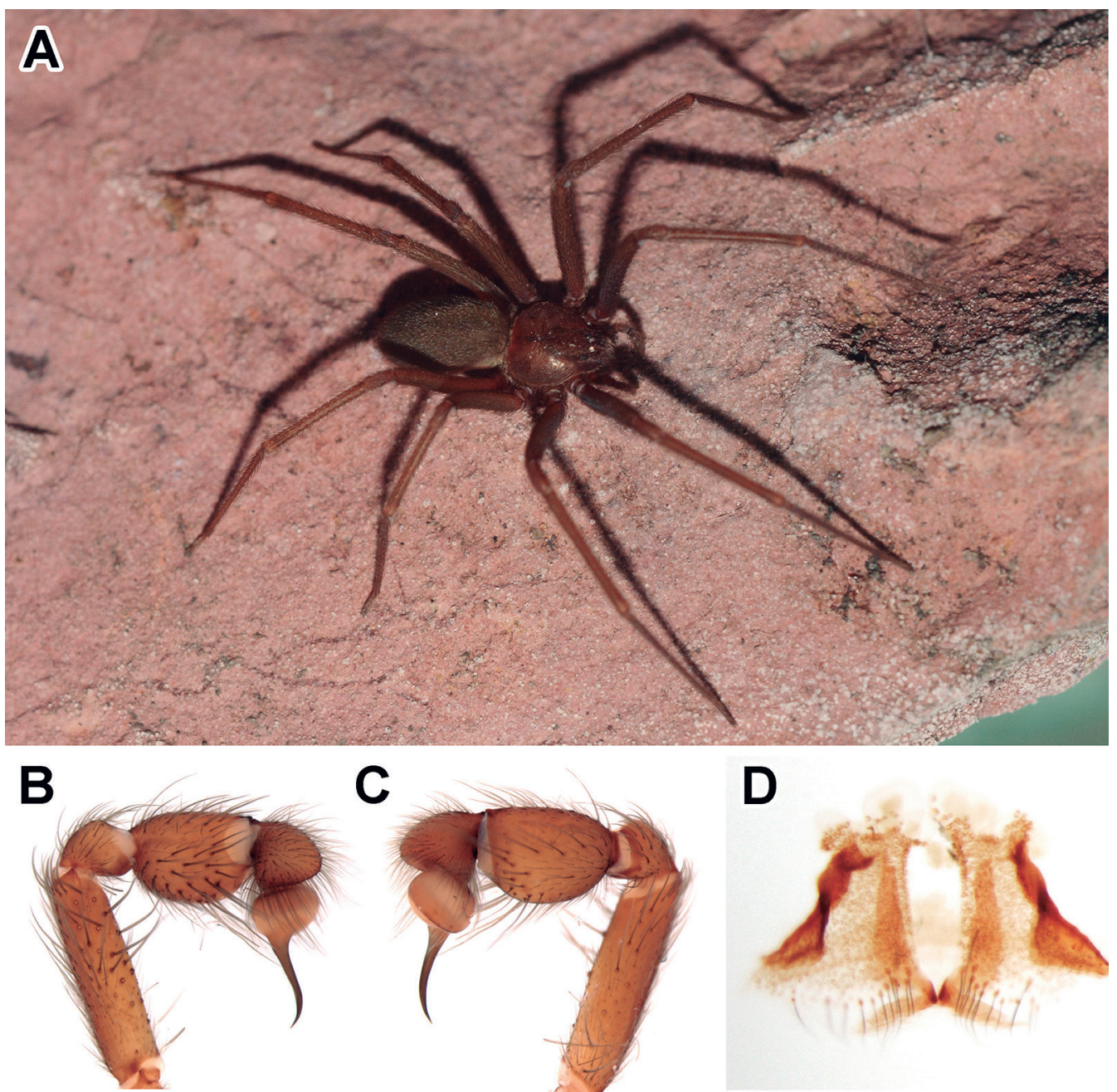

Figure 4. Loxosceles amazonica. (A) (Female), live specimen. (B) palp, retrolateral view; (C) palp, prolateral view. (D) spermathecae, ventral view.

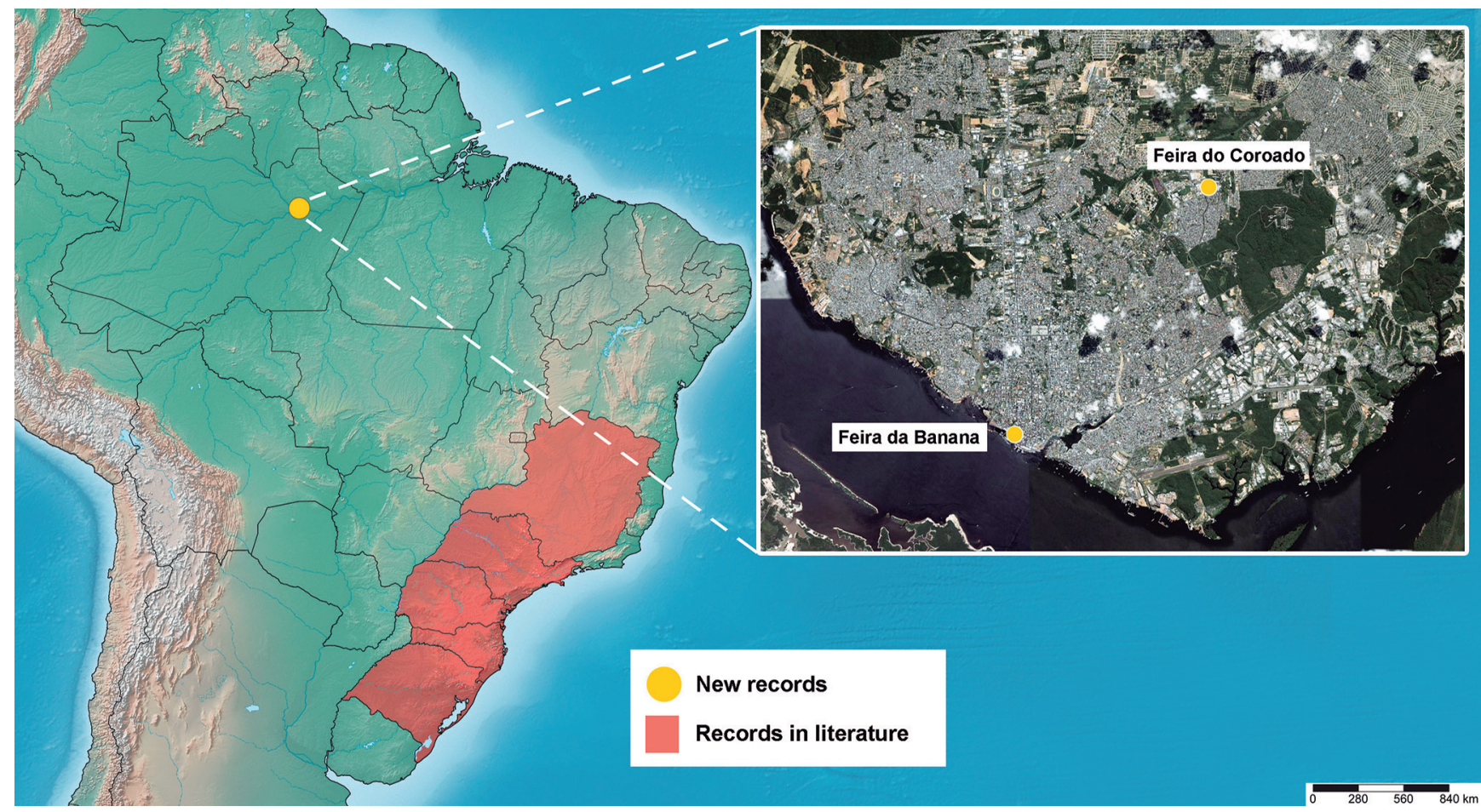

Figure 5. Map showing records of L. gaucho in Brazil. It is indicated in brown the Brazilian states with records in literature: São Paulo and Minas Gerais (Gertsch, 1967; Cardoso et al., 2003), Paraná and Rio Grande do Sul (Gertsch, 1967; Fischer, 1994). In yellow the new record in the state of Amazonas, Manaus city. 
whereas the Northeast has the most species recorded (11 species) (Table 1 ).

\section{DISCUSSION}

The introduction of non-native species can cause serious risks to local biodiversity and some species has the potential to cause envenomation of humans, such as spiders and scorpions (Mack et al., 2000; Silveira, 2009; Duncan et al., 2010; Bertani et al., 2018a).

Most probably, L. gaucho was accidentally introduced in the city of Manaus alongside the trade of fruits, vegetables and other goods from the Southeast region to the North region of the country, since these spiders were collected in farmers' market in the city (Fig. 5). This species seems to be well adapted to the region's climate and already has established populations, since egg sacs were collected (Fig. 3B) and also a large number of immatures were collected in one of the localities (Fig. 3C). Those spiders adapt themselves very well in the urban environment due to its various types of shelters (boxes, holes, debris), high availability of alimentary resources and the scarcity of natural predators.

Duncan et al. (2010) reported that a female specimen of Loxosceles was identified by Brignoli (1976) as L. gaucho in Tunisia, which has somatic and spermathecae morphology indistinguishable from Brazilian L. gaucho. The formerly mentioned authors discuss that the Tunisian specimen is a representative of another population of L. gaucho that has dispersed across the Atlantic through human trade activities. This idea is supported by the fact that the Tunisian L. gaucho was found near Sfax, the major port and commercial hub in the Mediterranean and a likely place to have introduced species. The city of Manaus is also a city with a large portuary activity although fluvial and the introduction of $L$. gaucho in Manaus may have been due to this way.

This is the first record of accidental introduction of a venomous animal in the state of Amazonas (Fig. 5). Finally, we hope than beside alert the Public Health Agencies, this led to the discussion of preventive measures to reduce the potential damage to human health and the necessity of having measures to control the identified focus for this species in Manaus.

\section{ACKNOWLEDGMENTS}

We thank the Invertebrates Collection of the Instituto Nacional de Pesquisas da Amazônia (INPA) for allowing the use of photographic equipment used in this work. M.Q.A. thanks particularly the support for the CNPq for the Ph.D. scholarship (Process: 140081/2019-4). R.S. acknowledges Fundação de Amparo à Pesquisa do Estado do Amazonas (FAPEAM) for the Ph.D. scholarship (Process 002/2016 - POSGRAD 2017). A.M.S.N. thanks particularly the support for the Capes-INPA research grant (Process: 88887.312051/2018-00). D.M.M.M. thanks particularly the support for the CNPq research grant
(Process: $141878 / 2018-5)$. We thank the anonymous reviewers greatly contributed to the improvement of the manuscript.

\section{REFERENCES}

Almeida, M.Q.; Salvatierra, L.; Carvalho, T.G.; Prestes, F.J; Brescovit, A.D. \& Gasnier, T. 2017. Long time not seen: Expanding the records of Loxosceles amazonica (Araneae: Sicariidae) in the Amazonas state, Brazil. Acta Amazonica, 47(2): 163-166.

Barbaro, K.C. \& Cardoso, J.L.C. 2003. Mecanismo de ação do veneno de Loxosceles e aspectos clínicos do loxoscelismo. In: Cardoso, J.L.C.; França, F.O.S.; Wen, F.H.; Santanna Málaque, C.M. \& Haddad, V. (Eds.). Animais peçonhentos no Brasil: biologia, clínica e terapêutica dos acidentes. São Paulo, Sarvier. p. 160-174.

Bertani, R.; Bonini, R.K.; Toda, M.M.; Isa, L.S.; Figueiredo, J.V.A.; Santos, M.R. \& Ferraz, S.C. 2018a. Alien Scorpions in the municipality of São Paulo evidence of successful establishment of Tityus stigmurus (Thorell, 1876) and first records of Broteochactas parvulus Pocock, 1897, and Jaguajir rochae (Borelli, 1910). Biolnvasions Records, 7: 89-94.

Bertani, R.; von Schimonsky, D.M.; Gallão, J.E. \& Bichuette, M.E. 2018b. Four new troglophilic species of Loxosceles Heinecken \& Lowe, 1832: contributions to the knowledge of recluse spiders from Brazilian caves (Araneae, Sicariidae). ZooKeys, 806: 47-72.

Brignoli, P.M. 1976. Beiträge zur Kenntnis der Scytodidae (Araneae). Revue suisse Zoologie, 83: 125-191.

Cardoso, J.L.C.; França, F.D.S.; Wen, F.H.; Malaque, C.M.S. \& Haddad Jr, V. 2003. Animais peçonhentos no Brasil: biologia, clínica e terapêutica dos acidentes. Revista do Instituto de Medicina Tropical de São Paulo, 45(6): 338-338.

Duncan, R.P.; Rynerson, M.R.; Ribera, C. \& Binford, G. 2010. Diversity of Loxosceles spiders in Northwestern Africa and molecular support for cryptic species in the Loxosceles rufescens lineage. Molecular Phylogenetics and Evolution, 55: 234-248.

Fischer, M.L. 1994. Levantamento das espécies de Loxosceles Heinecken \& Lowe, 1832 no município de Curitiba, Paraná, Brasil. Estudos de Biologia, 3: 63-88.

Fukushima, C.S.; Andrade, R.M.G. \& Bertani, R. 2017. Two new Brazilian species of Loxosceles Heinecken \& Lowe, 1832 with remarks on amazonica and rufescens groups (Araneae, Sicariidae). ZooKeys, 667: 67-94.

Gertsch, W.J. 1967. The spider genus Loxosceles in South America (Araneae, Scytodidae). Bulletin of the American Museum of Natural History, 136: 117-174.

Gonçalves-de-Andrade, R.M.; Bertani, R.; Nagahama, R.H. \& Barbosa, M.F.R. 2012. Loxosceles niedeguidonae (Araneae, Sicariidae) a new species of brown spider from Brazilian semi-arid region. ZooKeys, 175: 27-36.

Mack, R.N.; Simberloff, D.; Lonsdale, M.W.; Evans, H.; Clout, M. \& Bazzaz, F.A. 2000. Biotic invasions: causes, epidemiology, global consequences, and control. Ecological Applications, 10: 689-710.

Marques-da-Silva, E. \& Fischer, M.L. 2005. Distribuição das espécies do gênero Loxosceles Heinecken \& Lowe, 1835 (Araneae; Sicariidae) no Estado do Paraná. Revista da Sociedade Brasileira de Medicina Tropical, 38(4): 331-335.

Martins, R.; Knysak, I. \& Bertani, R. 2002. A new species of Loxosceles of the laeta group from Brazil (Araneae: Sicariidae). Zootaxa, 94: 1-6.

Mello-Leitão, C.F. 1917. Notas arachnologicas. V. Especies novas ou pouco conhecidas do Brasil. Brotéria (Serie Zoológica), 15: 74-102.

Mello-Leitão, C.F. 1931. Arachnideos do Rio Grande do Sul. Boletim Biológico, São Paulo,17: 10-14. 
Mello-Leitão, C.F. 1934. Espécies brasileiras do genero Loxosceles Lowe. Anais da Academia Brasileira de Ciências, 6: 69-73.

Shorthouse, D.P. 2010. SimpleMappr, an online tool to produce publicationquality point maps. Available at: http://nolinoideae.e-monocot.org/ node/6. Access in: 29/03/2019.

Silveira, A.L. 2009. First synanthropic record of Loxosceles laeta (Nicolet, 1849) (Araneae, Sicariidae) in the municipality of Rio de Janeiro State of Rio de Janeiro. Revista da Sociedade Brasileira de Medicina Tropical, 42(6): 723-726.

Silveira, A.L. 2015. New geographic records of the brown spider Loxosceles amazonica Gertsch, 1967 (Araneae: Sicariidae) in Northeastern Brazil and its medical importance. Revista Médica de Minas Gerais, 25(1):37-45.
Souza, F.V.R. \& Ferreira, R.L. 2018. A new highly troglomorphic Loxosceles (Araneae: Sicariidae) from Brazil. Zootaxa, 4438(3): 575-587.

Swanson, D.L. \& Vetter, R.S. 2006. Loxoscelism. Clinics in Dermatology, 24(3): 213-221.

The world spider catalog, version 20.5. 2019. American Museum of Natural History (http://research.amnh.org/entomology/spiders/catalog/index. html). Access in: 26/09/2019.

Valdez-Mondragón, A.; Cortez-Roldán, M.R.; Juárez-Sánchez, A.R. \& Solís-Catalán, K.P. 2018. A new species of Loxosceles Heineken \& Lowe (Araneae, Sicariidae), with updated distribution records and biogeographical comments for the species from Mexico, including a new record of Loxosceles rufescens (Dufour). ZooKeys, 802: 39-66. 